\title{
TRANSURETHRAL EXTERNAL SPHINCTEROTOMY SANS EXTERNAL SPHINCTER
}

By M. S. RaO, M.S.; B. C. Bapna, F.R.C.S.(C); S. Vaidyanathan, M.S., M.Ch.; K. M. K. RaO, M.S.; C. L. Subudhi, M.S.; L. J. Rajendran, M.S. and V. V. ShriKHANDE, M.S.

Division of Urology, Department of Surgery, Postgraduate Institute of Medical Education and Research, Chandigarh, India

Abstract. Of 5I patients with detrusor-sphincter dyssynergia undergoing external urethral spincterotomy by transurethral resection, histological examination revealed no skeletal muscle in the resected tissue in six patients. The functional improvement which resulted in these cases despite this finding with an explanation for the same forms the topic of this paper.

Key words: Sphincterotomy; Detrusor-sphincter dyssynergic.

\section{Introduction}

IN the recent knowledge on the contribution of the proximal urethral and external sphincter area smooth muscle tissue towards voiding dynamics, we feel we have found an adequate explanation for the surprisingly successful results seen in some of our patients whose external urethral sphincter happened to remain unresected during attempted external sphincterotomy. Our decision to withhold a repeat sphincterotomy in such cases was rationalised on the basis of the improved functional results in correction of detrusor-sphincter dyssynergia in such a situation.

\section{Procedure}

Fifty-one consecutive external urethral sphincterotomies by resection under topical or no anaesthesia (Rao et al., 1977) were carried out for detrusor-sphincter dyssynergia. Histological confirmation of adequacy of the procedure was sought for in every case by detecting presence of striated muscle fibres in the resected specimens. Care was taken towards separation of collections of bladder neck and prostatic tissue on the one hand and material from the external sphincter area on the other, whenever a transurethral resection of the former was carried out in addition to the sphincterotomy procedure.

\section{Results}

The select group with the above combination of surprise findings comprised three cases of spinal injury (cervical-2; dorsal-I) and one each of transverse myelitis, cervical spondylosis and an obstructing prostate with a hypotonic bladder with no demonstrable associated neurologic disease. The last case had two unsuccessful T.U.R. procedures before sphincterotomy relieved his urinary retention. The surgery and post-operative period were uneventful. Following the sphincterotomy, voiding trial was given on the third post-operative day. Satisfactory functional results (confirmed by post-operative cysto-urethrography, cystometry and urethral profilometry) in terms of correction of dyssynergia with adequate 
lowering of post-void residual and reduction of urethral pressure profile especially in the peak pressure zone were achieved in all these six patients and have been maintained over at least a one-year follow-up period.

\section{Discussion}

In these patients, catheter-free trials happened to be given before the histological reports were received, a very fortuitous circumstance which encouraged us in withholding a repeat procedure, as the functional results achieved were satisfactory. The reason for this favourable result of a sphincterotomy even in the absence of striated muscle in resected tissue eluded us till our perusal of recent literature.

Traditionally it is believed that the external urethral sphincter constitutes the zone of maximal urethral resistance and is mainly responsible for the urethral obstruction in paraplegics. External sphincterotomy has been performed so as to lower the urethral resistance and restore efficient voiding in large numbers of patients with satisfactory results. However, haemorrhage and impotence continue to be the major complications of this procedure. It has been emphasised on the basis of anatomical studies that the incision for sphincterotomy should be $6 \mathrm{~mm}$ deep and $2 \mathrm{~cm}$ long extending from the verumontanum in order to adequately divide the skeletal muscle component (Linker and Tanagho, 1975). For the same reason, in sphincterotomy by resection, emphasis has been laid on detection of skeletal muscle fibres in the resected tissue (Nanninga et al., 1974)

Awad and Downie (I977) have clearly shown that the smooth muscle component of the urethral wall at the external sphincter site has functional importance in contribution towards normal continence as well as neurogenic obstruction. Sympathetically innervated smooth muscle and non-neural factors account for 85 per cent of the overall continence mechanism. The smooth muscles in the proximal urethra contribute 45 per cent to the urethral pressure profile in the male (Awad and Downie, 1976). Intravenous phentolamine produces a significant decrease in the peak pressure zone in the male which has been traditionally attributed to the external sphincter activity. It is now believed that the sympathetically innervated smooth muscle is responsible for the urethral wall tension in the peak pressure zone (Awad et al., 1976).

Colapinto and McCallum (1976) have emphasised the important role played by smooth muscle fibres lying immediately beneath the lining of the membranous urethra in maintaining continence in prostatectomised patients. Conversely, division of these smooth muscle fibres alone might relieve urethral obstruction in certain patients with neurogenic obstruction. Such patients could be recognised by test sympathetic blockade (phentolamine test) while performing voiding cystourethrography and urethral pressure profile studies (Awad and Downie, I977). Recognition of this group of patients would help to avoid performance of the classical external urethral spincterotomy.

In future, fractionation of the smooth and striated sphincter components by selective pharmacological blockade in a given patient of detrusor-sphincter dyssynergia may make it possible to arrive at a pre-operative estimate about whether deliberate incision or resection of the urethral smooth muscle alone at the external sphincter site would adequately serve the purpose of lowering peak urethral pressure to promote bladder emptying. The other attractive prospect, if this selection were to be rendered possible in a sizeable fraction of patients undergoing external sphincterotomy, is of lowering of serious haemorrhage and impotence 
risks. It has already been demonstrated that this operation could be undertaken under local or no anaesthesia in a sizeable number of cases, thus reducing the anaesthetic hazards which spinal injury cases are otherwise subject to (Rao et al., 1977).

Regarding the other alternative of therapeutic pharmacological blockade by single or combination of drugs to correct detrusor-sphincter dyssynergia, this awaits the test of time for clearer information on side-effects of these agents upon long-term usage, the average duration of use before the weaning-off phase once balanced bladder function is achieved, comparative costs involved in such longterm therapy (the last being particularly important for developing countries), skipped doses, etc. Until such a time, any improvement towards lowering the external sphincterotomy complication rate by more precise pre-operative functional assessment and in attempts towards refinement in patient selection and operative technique (including reduction of anaesthesia hazards) will continue to hold the attention of urologists dealing with detrusor-sphincter dyssynergia.

\section{[SUMMARY}

The fortuitous result of improved voiding in some of our patients despite absence of skeletal muscle in resected tissue after transurethral external sphincterotomy can now be explained on the basis of significant urethral smooth muscle contribution to the detrusor-sphincter dyssynergia getting corrected by this procedure. A plea is made to withhold the decision for an immediate repeat procedure when based purely on histological evidence of absence of striated muscle rather than by accepting the functional improvement in voiding dynamics after testing for these post-operatively.

\section{RÉSUMÉ}

Le résultat imprévu d'une meilleure évacuation chez certains de nos malades malgré l'absence de muscle squelettique dans le tissus reséqué à la suite d'une sphinctérotomie transuretrale externe, peut s'expliquer actuellement par le fait qu'à la suite de ce procédé le muscle uretral lisse contribue considérablement à la rectification de la dyssynergie muscle pubovesicalis/sphincter. Les auteurs recommandent de s'abstenir d'une répétition immédiate du procédé en s'appuyant uniquement sur l'évidence histologique concernant l'absence de muscle strié, am lieu d'accepter l'amélioration fonctionnelle dans la dynamique de l'évacuation après avoir vérifié cette dernière à la suite de l'opération.

\section{ZUSAMMENFASSUNG}

Das zufällige Ergebniss der verbesserten Leerung in eingen unseren Patienten trotz der Abwesenheit des Skelettmuskels in herausgeschnittnen Gewebe nach transurethralen äusseren Sphinkterotomie kann nun auf der Grundlage des Beitrages, gemacht durch den urethralen beträchtlichen gleichmässigen Muskel zu Detrusor-Spinkter Sinergiestörung, die durch dieses Verfahren berichtigt wird, erklärt werden. Es wird gebeten die Entscheidung in Bezug auf Wiederholungsverfahren basierend ausschliesslich auf histologischen Nachweis der Abwesenheit des Stria Muskel anstatt der Akzeptierung der funktionellen Besserung in Leerungsdynamik, nachdem diese postoperativ untersucht worden ist, zurückzuhalten.

\section{REFERENCES}

Awad, S. A. \& Downie, J. W. (1976). Relative contributions of smooth and striated muscles to the canine urethral pressure profile. Brit. F. Urol., 48, 347.

Awad, S. A., Downie, J. W., Lywood, D. W., Young, R. A. \& JARZYLo, S. V. (1976). Sympathetic activity in the proximal urethra in patients with urinary obstruction. f. Urol., 115, 545 . 
Awad, S. A. \& Downie, J. W. (I977). Sympathetic dyssynergia in the region of the external sphincter: A possible source of lower urinary tract obstruction. f. Urol., I18, 636.

Colapinto, V. \& McCallum, R. W. (1976). Urinary continence after repair of membranous urethral stricture in prostatectomized patients. F. Urol., I15, 392.

LinkeR, D. G. \& TANAGHo, E. A. (I 975). Complete external sphincterotomy: Correlation between endoscopic observation and the anatomic sphincter. F. Urol., 113, 348.

Nanninga, J. B., Rosen, J. \& O'ConoR, V. J. (1974). Experience with transurethral external sphincterotomy in patients with spinal cord injury. F. Urol., II2, 72.

Rao, M. S., Bapna, B. C., Vaidyanathan, S., Gupta, C. L., Bhat, V. N., RedDy, M. J., RAO, K. M. K. \& SINGH, H. (I977). Topical or no anesthesia for external urethral sphincterotomy in neurogenic vesical dysfunction due to spinal injury. Paraplegia, 15, 226 . 